Bull. Chem. Soc. Ethiop. 2013, 27(3), 359-366.

Printed in Ethiopia

DOI: http://dx.doi.org/10.4314/bcse.v27i3.4

ISSN 1011-3924

(c) 2013 Chemical Society of Ethiopia

\title{
DETERMINATION OF THIOBENCARB IN WATER SAMPLES BY GAS CHROMATOGRAPHY USING A HOMOGENEOUS LIQUID-LIQUID MICROEXTRACTION VIA FLOTATION ASSISTANCE PROCEDURE
}

\author{
Hossein Ali Mashayekhi ${ }^{*}$ \\ Department of Chemistry, Tonekabon Branch, Islamic Azad University, Tonekabon, Iran
}

(Received April 3, 2013; revised July 31, 2013)

\begin{abstract}
Homogeneous liquid-liquid microextraction via flotation assistance (HLLME-FA) coupled with gas chromatography-flame ionization detection (GC-FID) was applied for the extraction and determination of thiobencarb in water samples. In this study, a special extraction cell was designed to facilitate collection of the low-density solvent extraction. No centrifugation was required in this procedure. The water sample solution was added into the extraction cell which contained an appropriate mixture of toluene (as an extraction solvent) and acetone (as a homogeneous solvent). By using air flotation, the organic solvent was collected at the conical part of the designed cell. The effect of the different parameters on the efficiency of extraction such as type and volume of extraction and homogeneous solvents, ionic strength and extraction time were studied and optimized. Under the optimal conditions, linearity of the method was in the range of $1.0-200 \mu \mathrm{g} \mathrm{L}^{-1}$. The relative standard deviations in the real samples varied from $7.8-11.7 \%(n=3)$. The proposed method was successfully applied to analysis of thiobencarb in the water samples and satisfactory results were obtained.
\end{abstract}

KEY WORDS: Homogeneous liquid-liquid microextraction, Flotation assistance, Thiobencarb, Gas chromatography, Water samples

\section{INTRODUCTION}

Thiobencarb, S-4-chlorobenzyl N,N-diethylthiocarbamate, is a thiocarbamate herbicide that has been extensively used in modern agricultural practices for the control of barnyard grass in paddy rice fields. Application of this herbicide results in its residue in water. It is well known that their application may be a contaminant source for aquatic environment. The monitoring of thiobencarb residues is very important to assess safety of the environment. The analysis of thiobencarb performed by gas chromatography (GC) or gas chromatography with mass spectrometry (GC-MS) and selected ion monitoring requires several cleanup steps [1-4] and is time consuming and labor intensive. Therefore, development of a sensitive, convenient and economical method is required for the analysis of the residues in water samples. Recently, immunoassays have been used as alternative or complementary methods for the analysis of thiobencarb [5]. The principle of competitive immunoassay is based on a specific competitive reaction between antigen (thiobencarb and thiobencarb tracer) and antibody (anti-thiobencarb antibody).

A new procedure, called dispersive liquid-liquid microextraction (DLLME) has received much attention for sample pretreatment [6-10]. In this method, an appropriate mixture of the extraction solvent and dispersive solvent is injected into the aqueous sample by a syringe to form a cloudy solution. The cloudy solution is then centrifuged and the fine droplets sedimented at the bottom of the conical test tube. Determination of the analytes in the sedimented phase can be performed by instrumental techniques.

Homogeneous liquid-liquid extraction (HLLE) utilizes phase separation phenomenon from a homogeneous solution, and target solutes are extracted into a separated phase. The procedure is simple and requires only addition of a reagent. The ternary component solvent system and the perfluorinated surfactant system are the two usual modes of HLLE [11-13].

*Corresponding author. E-mail: chem.mashayekhi@toniau.ac.ir 
The main disadvantage of ternary systems including HLLE and DLLME is that the extraction solvent is generally limited to solvents of higher density than water in order to be sedimented by centrifugation. These solvents are typically chlorinated such as chlorobenzene, chloroform, and carbon tetrachloride, all of which are potentially toxic to humans and the environment. In addition, the use of high density solvents as extractant limits wider applicability of DLLME and HLLE. To overcome this limitation, several studies have reported the application of low density solvents in solvent microextraction methods in recent years [14-23].

Typically, most DLLME and HLLE methods have a centrifugation step, which an extra time-consuming step in the extraction. Very recently, solvent-terminated DLLME was developed by $\mathrm{Li}$ and co-workers [24] as an alternative approach. The method avoids centrifugation; thus, simplifies the operation and speeds up the extraction procedure.

Homogeneous liquid-liquid microextraction via flotation assistance (HLLME-FA) method was developed for the determination of polycyclic aromatic hydrocarbons (PAHs) in soil and water samples $[25,26]$. The aim of this study was to develop HLLME-FA method for the preconcentration and determination of trace amounts of thiobencarb in water samples. To the best of our knowledge, this methodology has not been employed in the extraction and determination of trace amounts of thiobencarb from water samples. In this procedure, a mixture of extraction solvent and homogeneous solvent is injected into an aqueous sample to form a homogeneous solution in the initial state and then form an emulsion consisting of fine droplets of the extraction solvent, homogeneous solvent and water. In this method, a special extraction cell was designed to facilitate collection of the low-density solvent extraction. No centrifugation was required in this procedure. By using air flotation, the organic solvent was collected at the conical part of the designed cell. The most effective variables on the HLLME-FA method could be considered as the type and volume of extraction solvent, ionic strength, the type and volume of homogeneous solvent and time of extraction.

\section{Chemicals and reagents}

\section{EXPERIMENTAL}

Thiobencarb and sodium chloride of the highest purity available from Merck (Darmstadt, Germany) were used in this study. A stock standard solution of thiobencarb (1000 $\left.\mathrm{mg} \mathrm{L}^{-1}\right)$ was prepared in methanol. A fresh $10 \mathrm{mg} \mathrm{L}^{-1}$ standard solution containing the analyte was prepared in methanol every week and stored at $4{ }^{\circ} \mathrm{C}$. The working standard solutions were prepared in doubly distilled water, stored at $4{ }^{\circ} \mathrm{C}$ in fridge, and brought to ambient temperature prior to use. n-Hexane, n-heptane, toluene, 1-octanol, methanol, acetone and acetonitrile were obtained from Merck (Darmstadt, Germany). Youngling ultra pure water purification system (Aqua Max ${ }^{\mathrm{TM}}$ ultra, Korea) was used for purification of water.

\section{Instrumentation}

Separation and quantification of thiobencarb were carried out using an Agilent 7890 gas chromatograph, equipped with a FID detector and a DB-5 fused-silica capillary column $(30 \mathrm{~m} \times$ $0.32 \mathrm{~mm}$ i.d. $\times 0.25 \mu \mathrm{m}$ film thickness). Injection was performed at splitless mode, and helium gas with high purity was used as a carrier gas at the constant flow rate of $1.5 \mathrm{~mL} \mathrm{~min}^{-1}$. The injector and detector temperatures were 260 and $270{ }^{\circ} \mathrm{C}$, respectively. The column temperature program was as follows: $120^{\circ} \mathrm{C}$ for $1 \mathrm{~min}$, increased to $270{ }^{\circ} \mathrm{C}$ at $10{ }^{\circ} \mathrm{C} \mathrm{min}{ }^{-1}$, and then held for $3 \mathrm{~min}$. The analytical signal was taken as the peak area of the analyte. 
HLLME-FA procedure

Figure 1 shows the schematic procedure of the proposed method. A mixture of $0.5 \mathrm{~mL}$ acetone (homogeneous solvent) and $50 \mu \mathrm{L}$ toluene (extraction solvent) were added to the homedesigned microextraction cell (Figure 1-1). A volume of $22 \mathrm{~mL}$ of the saline aqueous sample solution was injected into the microextraction cell by syringe, rapidly (Figure 1-2). In this step, in the initial state of injection, a homogeneous solution was formed and then with the continuation of injection an emulsion consisting of fine droplets of the extraction solvent were formed (Figure 1-3). After about $5 \mathrm{~min}$, by using air flotation, the organic solvent was collected on the top of the solution (Figure 1-4). After separation of the two phases, $2.0 \mathrm{~mL}$ of distilled water were added into the glass tube on the side of the cell (Figure 1-5). The floated organic solvent was raised into the conical part of the cell. Using a microsyringe, two microliters of the collected organic solvent were injected into the GC-FID instrument.

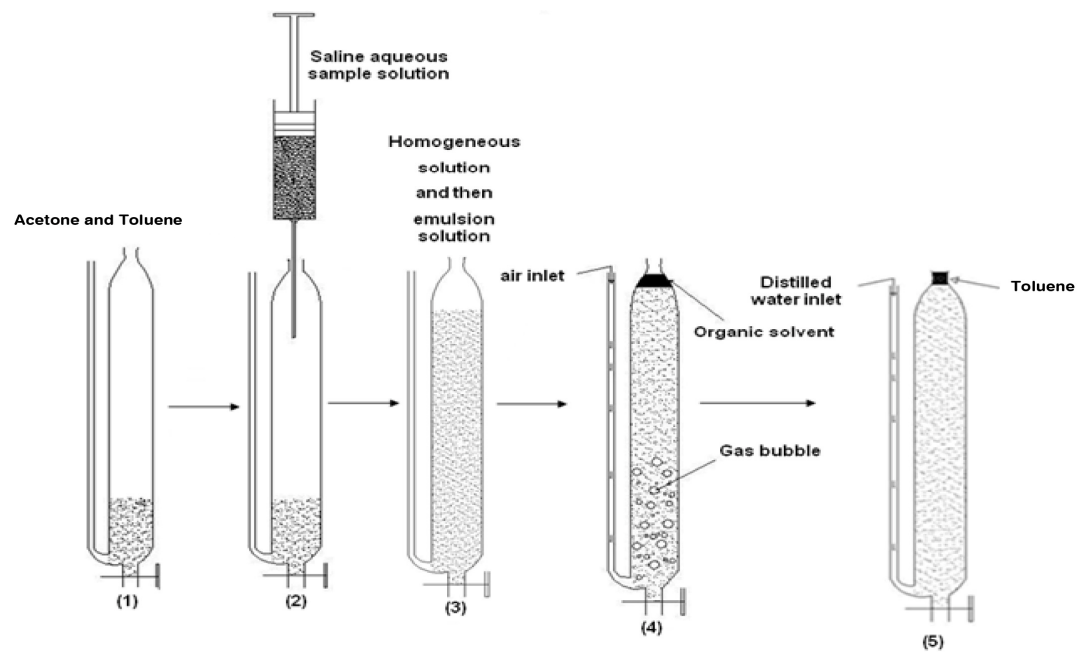

Figure 1. Schematic HLLME-FA procedure (Figure 1-1) a mixture of $0.5 \mathrm{~mL}$ acetone containing $50.0 \mu \mathrm{L}$ toluene was added to the home-designed microextraction cell, (Figure 1-2) $22.0 \mathrm{~mL}$ of the saline aqueous solution was added into the microextraction cell, (Figure 1-3) a homogeneous solution was formed in the cell, (Figure 1-4) using air flotation, organic solvent was moved to the top of the solution, (Figure 1-5) a small volume of distilled water was added into the glass tube on the side of the cell.

\section{RESULTS AND DISCUSSIONS}

This study explored the applicability of the HLLME-FA method to the analysis of thiobencarb in the aqueous matrices. The effect of a number of variables, including the type and volume of extraction and homogeneous solvents, ionic strength and extraction time on the sensitivity of the method was examined.

\section{Selection of extraction solvent}

Selection of an appropriate extraction solvent is of great importance in optimization of the HFHLLME method. Different low density solvents (1-octanol, n-hexane, n-heptane, and toluene) with different polarity and water solubility values were tested for this purpose. It is necessary to 
add an excess amount of solvent to recover an equal volume of different extraction solvents in the upper layer for comparison. The final volume of the floated solvents was kept at $6.0 \mu \mathrm{L}$. The results are provided in Figure 2. As shown in Figure 2, toluene showed the highest extraction efficiency. It seems, because the structure of interested analyte has benzene group and interaction with benzene group in toluene causes better extraction efficiency. Thus, toluene was selected for subsequent experiments.

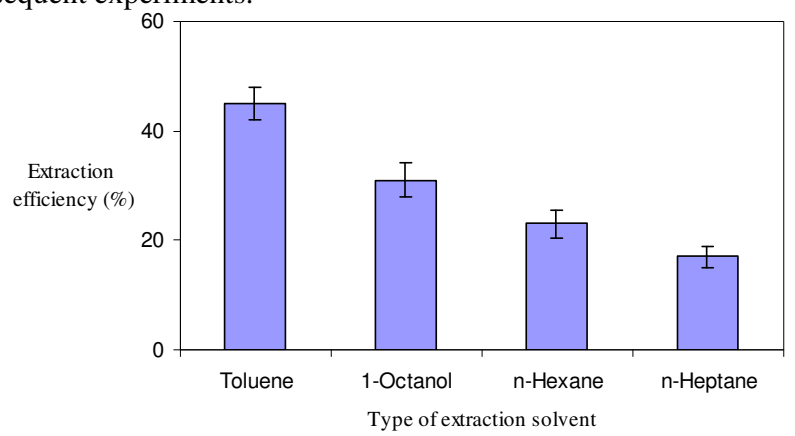

Figure 2. Effect of type of extraction solvent on the extraction efficiency.

\section{Selection of homogeneous solvent}

Miscibility of homogeneous solvent in the extraction solvent and aqueous phase is the main point for selection of a homogeneous solvent. Therefore, acetone, acetonitrile and methanol were selected for this purpose. A series of sample solutions was studied by using $0.5 \mathrm{~mL}$ of each homogeneous solvent containing $50.0 \mu \mathrm{L}$ of toluene (as the extraction solvent). The results showed that variation of the extraction recoveries using different homogeneous solvents was not remarkable. Therefore, acetone was selected as the homogeneous solvent because of less toxicity and low cost.

\section{Selection of extraction and homogeneous solvent volumes}

To examine the effect of extraction solvent volume, different amounts of toluene $(50.0,60.0$, 70.0, 80.0, and $90.0 \mu \mathrm{L}$ ) were evaluated. Precocentration factor (PF) was calculated using the equation: $\mathrm{PF}=\mathrm{C}_{\text {collected }} / \mathrm{C}_{\text {initial }}$, where $\mathrm{C}_{\text {collected }}$ is concentration of the analyte in the collected organic phase and $\mathrm{C}_{\text {initial }}$ the initial concentration of the analyte in the sample solution. With increasing volume of extraction solvent, the volume of collected organic phase increased, which resulted in a decrease in the concentration of the analyte in the collected organic phase. Based on the experimental results (Figure 3), $50.0 \mu \mathrm{L}$ of toluene was adopted for the further experiments. In order to study the influence of the volume of the homogeneous solvent on the extraction efficiency, different volumes of acetone $(0.5,1.0,1.5$ and $2.0 \mathrm{~mL})$ were used. The results (Figure 4) showed that with an increase in the homogeneous solvent volume (acetone), the extraction efficiency decreased possibly due to an increase in lipophilicity of the aqueous solution and a decrease in distribution constant. Thus, $0.5 \mathrm{~mL}$ acetone was chosen in this work.

\section{Effect of salt addition}

Effect of salt addition on the extraction efficiency was studied by changing $\mathrm{NaCl}$ concentration from 0.5 to $3 \mathrm{M}$. Figure 5 demonstrates the extraction efficiency of the analyte versus concentration of $\mathrm{NaCl}$. By increasing the $\mathrm{NaCl}$ concentration up to $1.5 \mathrm{M}$, the extraction efficiency of the analyte increases because of salting-out effect. Higher than $1.5 \mathrm{M}$ of salt decreased extraction efficiency because of increased solution viscosity that reduces dispersion 
phenomenon. Therefore, $1.5 \mathrm{M}$ of $\mathrm{NaCl}$ was selected as the optimal value for subsequent analysis.

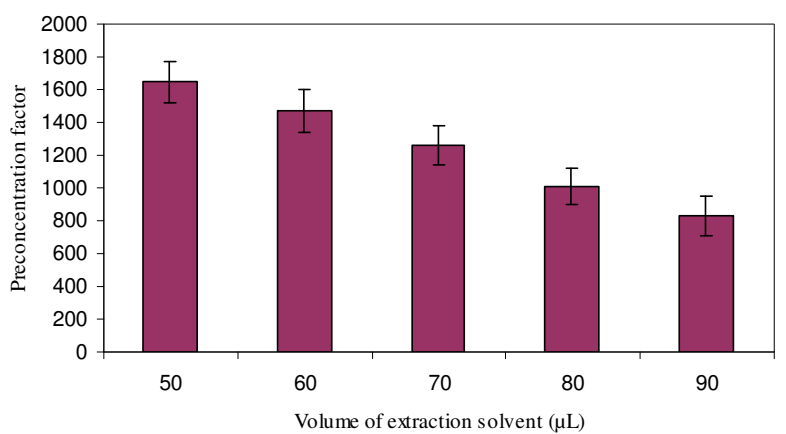

Figure 3. Effect of volume of extraction solvent on the preconcentration factor.

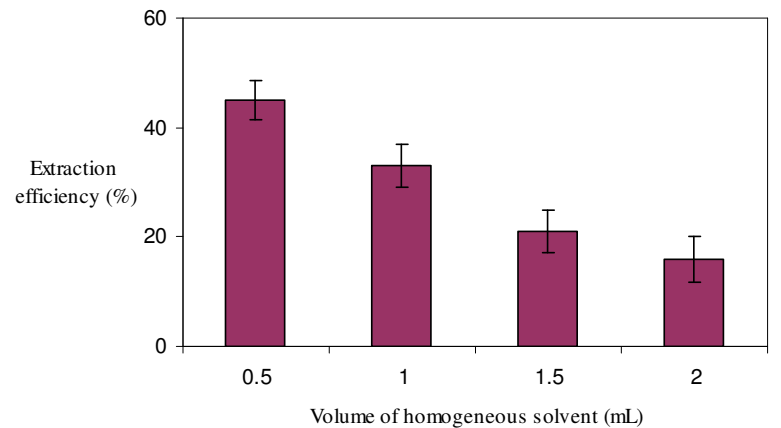

Figure 4. Effect of volume of homogeneous solvent on the extraction efficiency.

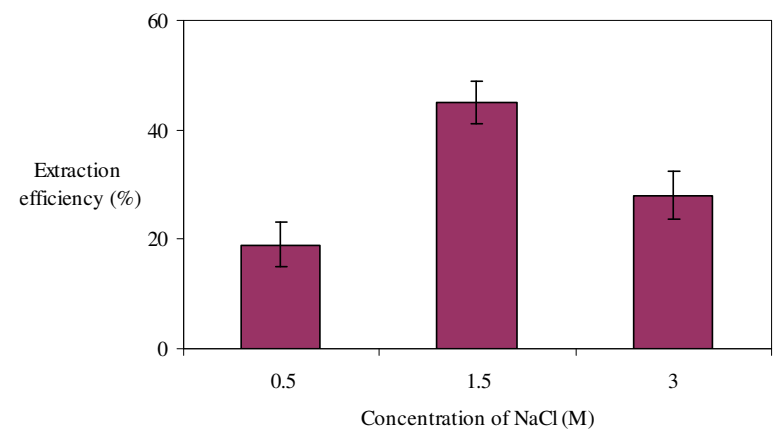

Figure 5. Effect of $\mathrm{NaCl}$ concentration on the extraction efficiency.

\section{Effect of extraction time}

In this experiment, extraction time is the interval time between the beginning of the dispersion and the end of dispersion just before air flotation. Effect of extraction time was examined in the time range of 1-15 min. The results (Figure 6) show that extraction time has no significant effect on the extraction efficiency of the analyte, because of large surface area between the extraction solvent and the sample solution. Hence, in the following experiments, the extraction time of 1 min was adopted to achieve maximal extraction efficiency of the analyte. 


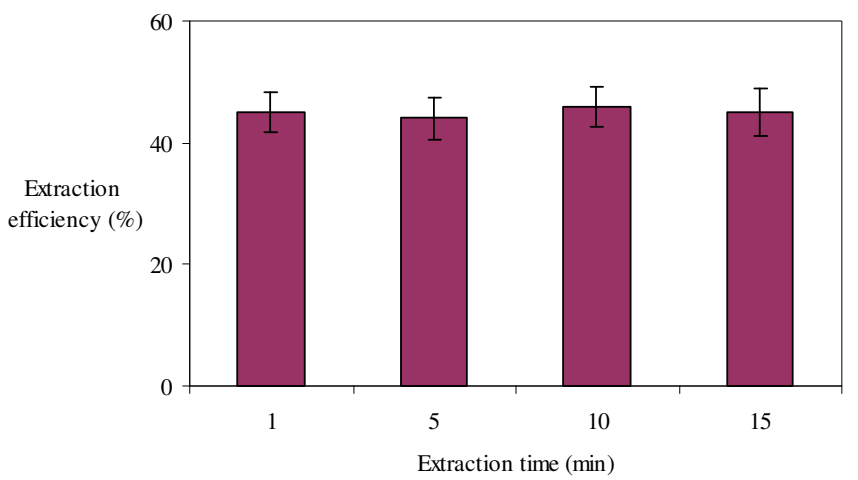

Figure 6. Effect of extraction time on the extraction efficiency.

\section{Analytical figures of merit}

The characteristics of the calibration curve were obtained under the optimized conditions. Linearity was observed in the range of 1.0-200 $\mu \mathrm{g} \mathrm{L}^{-1}$ for thiobencarb with coefficient of correlation $(r)$ of 0.9987 . The relative standard deviation $(\mathrm{RSD})$ was $8.1 \%(\mathrm{n}=4)$ and the mean precisions obtained from more than six duplicate experiments was $9.1 \%$. The limit of detection (LOD), based on signal-to-noise $(S / N)$ of three was $0.3 \mu \mathrm{g} \mathrm{L}^{-1}$. Table 1 compares the proposed method with other extraction methods for determination of thiobencarb. Comparison of the proposed method with solid-phase extraction [27] and competitive enzyme-labelled immunosorbent assay (C-ELISAs) [5] for extraction of thiobencarb indicates that this novel method has a short extraction time. Analytical figures of merit of proposed method such as detection limit and linear range are better than C-ELISAs and comparable with SPE method. Also, C-ELISAs method is expensive and needs more organic solvents. Finally, it can be concluded that the proposed method is an efficient, rapid, simple and cheep microextraction method that can be a complement technique for DLLME and HLLE method that have been used with organic solvents more dense than water for determination of thiobencarb in water samples.

\section{Real water analysis}

During the present investigation, matrix effects on the extraction were also evaluated by determining thiobencarb concentration in river, tap and well water samples. These samples were extracted using HLLME-FA method and analyzed by GC-FID. The results from tap, river and well water samples showed that they were free of thiobencarb contamination. These samples were spiked with thiobencarb standard at $5.0 \mu \mathrm{g} \mathrm{L}^{-1}$ level to assess matrix effects. Figure 7 shows the chromatograms obtained for unspiked and spiked river water. Relative recoveries were between 90 and $94 \%$. These results (Table 2) demonstrate that the tap, well and river water matrices, in our present context, had little effect on the HLLME-FA method.

Table 1. Comparison of the proposed method with other extraction methods for determination of thiobencarb.

\begin{tabular}{|l|c|c|c|c|c|}
\hline Method & RSD\% & $\begin{array}{c}\text { Dynamic linear } \\
\text { range }\left(\mu \mathrm{g} \mathrm{L}^{-1}\right)\end{array}$ & $\begin{array}{c}\text { Limit of detection } \\
\left(\mu \mathrm{g} \mathrm{L}^{-1}\right)\end{array}$ & $\begin{array}{c}\text { Extraction time } \\
(\mathrm{min})\end{array}$ & Ref. \\
\hline SPE-GC-FPD & 3.9 & $0.62-15$ & 0.1 & 5 & {$[27]$} \\
\hline C-ELISAs* & - & $5-100$ & - & 10 & {$[5]$} \\
\hline HLLME-FA-GC-FID & 8.1 & $1.0-200$ & 0.3 & 1 & This work \\
\hline
\end{tabular}

*C-ELISAs - Competitive enzyme-labelled immunosorbent assay. 


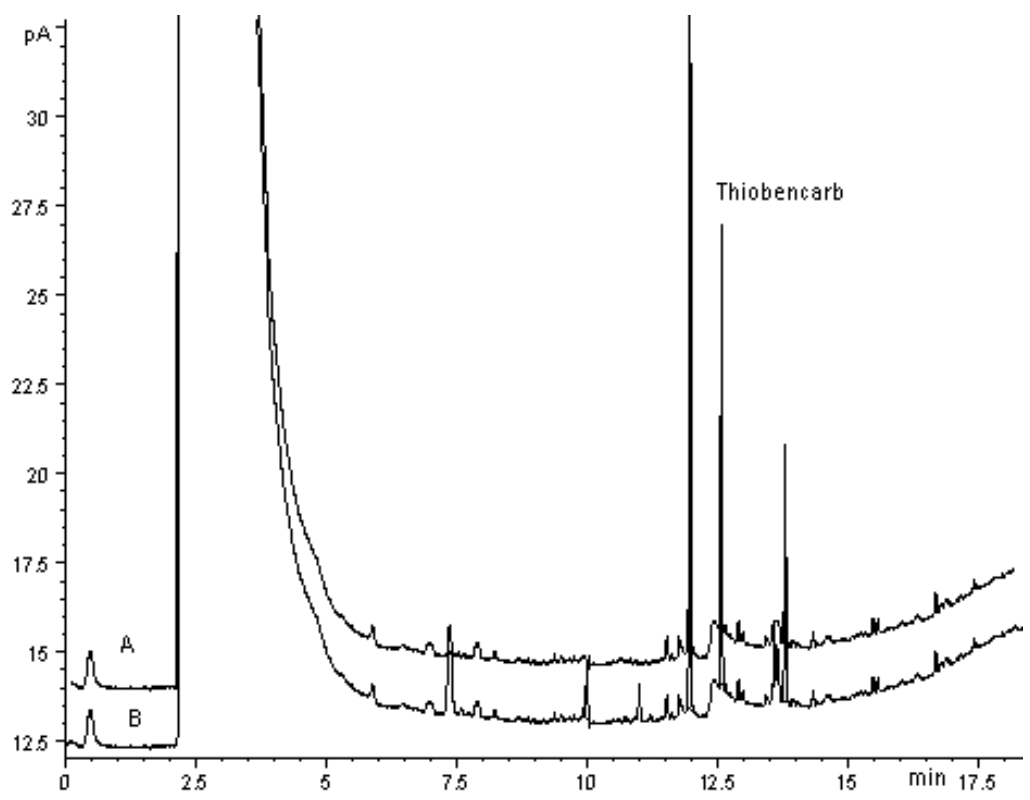

Figure 7. GC-FID chromatograms of analyte in river water, before spiking (A) and after spiking with $5.0 \mu \mathrm{g} \mathrm{L}^{-1}$ of thiobencarb (B) using proposed method combined with GC-FID under the optimum conditions.

Table 2. Determination of thiobencarb in tap, well and river water and relative recovery of spiked thiobencarb in them.

\begin{tabular}{|c|c|c|c|c|}
\hline Sample & $\begin{array}{l}\text { Concentration of } \\
\text { thiobencarb }\left(\mu \mathrm{g} \mathrm{L}^{-1}\right)\end{array}$ & $\begin{array}{l}\text { Added thiobencarb } \\
\qquad\left(\mu \mathrm{g} \mathrm{L}^{-1}\right)\end{array}$ & $\begin{array}{l}\text { Found thiobencarb } \\
\left(\mu \mathrm{g} \mathrm{L}^{-1}\right) \pm \mathrm{RSD}, \mathrm{n}=3\end{array}$ & $\begin{array}{l}\text { Relative } \\
\text { recovery (\%) }\end{array}$ \\
\hline Tap water ${ }^{\mathrm{a}}$ & Not detected & 5.0 & $4.7 \pm 7.8$ & 94 \\
\hline Well water ${ }^{b}$ & Not detected & 5.0 & $4.6 \pm 9.4$ & 92 \\
\hline River water $^{\mathrm{c}}$ & Not detected & 5.0 & $4.5 \pm 11.7$ & 90 \\
\hline
\end{tabular}

${ }^{a}$ The water was taken from Tonekabon Branch, Islamic Azad University (Tonekabon, Iran). ${ }^{\mathrm{b}}$ The water was collected from well in Tonekabon (Tonekabon, Iran). ${ }^{\mathrm{C}}$ The sample was collected from Langrud River (Gilan, Iran).

\section{CONCLUSION}

This paper describes the application of the HLLME-FA method combined with GC-FID for the determination of trace amounts of thiobencarb in water samples. The relative recoveries for thiobencarb were in the range of $90 \%-94 \%$ and demonstrated that tap, well and river water matrices had little effect on the HLLME-FA method. The method is precise, reproducible and linear over a wide range and requires small volumes of organic extractant. The new procedure of HLLME-FA does not need centrifugation to separate the organic phase. In this method, air flotation was used to break up the organic-in water emulsion and to finish the extraction process. 


\section{ACKNOWLEDGEMENT}

Financial support by Tonekabon Branch, Islamic Azad University (Tonekabon, Iran) for the support during the period of this research is gratefully acknowledged.

\section{REFERENCES}

1. Ishikawa, K.; Shinohara, R.; Akasaki, K. Agric. Biol. Chem. 1971, 35, 1161.

2. Kobayashi, H.; Ohyama, K.; Tomiyama, N.; Jimbo, Y.; Matano, O.; Goto, S. J. Chromatogr. A 1993, 643, 197.

3. Redondo, M.J.; Ruiz, M.J.; Boluda, R.; Font, G. J. Chromatogr. A 1994, 678, 375.

4. Takeda, M.; Ito, Y.; Odanaka, Y.; Komatsu, K.; Maekawa, Y.; Matano, O.; Zanryu, N.; Kenkyuhan, B. (Eds.), Saishin No Zanryu Bunsekiho (in Japanese), Chuo Hoki Publishing: Tokyo; 1995; pp 619-621.

5. Miyake, S.; Ito, S.; Yamaguchi, Y.; Beppu, Y.; Takewaki, S.; Yuasa, Y. Anal. Chim. Acta 1998, 376, 97.

6. Rezaee, M.; Assadi, Y.; Milani Hosseini, M.R.; Aghaee, E.; Ahmadi, F.; Berijani, S. J. Chromatogr. A 2006, 1116, 1.

7. Rezaee, M.; Yamini, Y.; Faraji, M. J. Chromatogr. A 2010, 1217, 2342.

8. Mashayekhi, H.A.; Abroomand-Azar, P.; Saber-Tehrani, M.; Husain, S.W. Chromatographia 2010, 71, 517.

9. Mashayekhi, H.A.; Abroomand-Azar, P.; Saber-Tehrani, M.; Waqif, S.H. Int. J. Environ. Anal. Chem. 2011, 91, 516.

10. Mashayekhi, H.A.; Rezaee, M.; Sadeghi Garmaroudi, S.; Montazeri, N.; Ahmadi, S.J. Anal. Sci. 2011, 27, 865 .

11. Oshite, S.; Furukawa, M.; Igarashi, S. Analyst 2001, 126, 703.

12. Takagai, Y.; Igarashi, S. Analyst 2001, 126, 551.

13. Igarashi, S.; Takahashi, A.; Ueki, Y.; Yamaguchi, H. Analyst 2000, 125, 797.

14. Farajzadeh, M.A.; Seyedi, S.E.; Shalamzali, M.S.; Bamorowat, M. J. Sep. Sci. 2009, 32, 3191.

15. Saleh, A.; Yamini, Y.; Faraji, M.; Rezaee, M.; Ghambarian, M. J. Chromatogr. A 2009, 1216, 6673 .

16. Leong, M.; Huang, S.D. J. Chromatogr. A 2008, $1211,8$.

17. Zhou, Q.; Bai, H.; Xie, G.; Xiao, J. J. Chromatogr. A 2008, 1188, 148.

18. Kocurova, L.; Balogh, I.S.; Sandrejova, J.; Andruch, V. Microchem. J. 2012, 102, 11.

19. Hashemi, P.; Beyranvand, S.; Siah Mansur, R.; Ghiasvand, A.R. Anal. Chim. Acta 2009, 655,60 .

20. Farajzadeh, M.A.; Djozan, Dj.; Fazeli Bakhtiyari, R. Talanta 2010, 81, 1360.

21. Rodriguez-Cabo, T.; Rodriguez, I.; Ramil, M.; Cela, R. J. Chromatogr. A 2011, 1218, 6603.

22. Ghambari, H.; Hadjmohammadi, M.R. J. Chromatogr. B 2012, 899, 66.

23. Guo, L.; Lee, H.K. J. Chromatogr. A 2011, 1218, 5040.

24. Chen, H.; Chen, R.W.; Li, S.Q. J. Chromatogr. A 2010, 1217, 1244.

25. Haji Hosseini, M.; Rezaee, M.; Mashayekhi, H.A.; Akbarian, S.; Mizani, F.; Pourjavid, M.R. J. Chromatogr. A 2012, 1265, 52.

26. Haji Hosseini, M.; Rezaee, M.; Mashayekhi, H.A.; Akbarian, S.; Mizani, F.; Pourjavid, M.R.; Arabieh, M. Anal. Chim. Acta 2013, 762, 54.

27. Rezaee, R.; Hassanzadeh-khayyat, M.; Mehri, F.; Khashyarmanesh, Z.; Moallemzadeh, H.; Karimi, G. Drug Chem. Toxicol. 2011, 5, 1. 